\title{
Nutritional status of cherry tomato with omission of macronutrients
}

\author{
Hosana Aguiar Freitas de Andrade ${ }^{1} \mathbb{0}$, Isadora Gomes Vieira ${ }^{1}$, lana Maria de Souza Oliveira ${ }^{1} \oplus$,

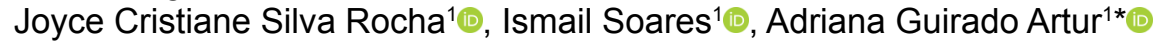

\footnotetext{
1 Universidade Federal do Ceará, Fortaleza, CE, Brasil. E-mail: hosana_f.andrade@hotmail.com; isadoragvi@hotmail.com; ianamaria_oliveira@hotmail.com; joycejoao02@gmail.com; ismail@ufc.br; driguirado@yahoo.com.br
}

ABSTRACT: Aspects related to tomato (Solanum lycopersicum L.) mineral nutrition are important for the production of quality fruits. The cherry tomato (Solanum lycopersicum var. cerasiforme) is an alternative for most producers due to its high market value, greater productivity and good acceptance by consumers. The objective with this study was to evaluate the nutritional status of cherry tomatoes cultivated in nutrient solution under omission of macronutrients. The experiment was conducted in a completely randomized design, with seven treatments: complete nutrient solution and omissions of $\mathrm{N}, \mathrm{P}, \mathrm{K}, \mathrm{Ca}, \mathrm{Mg}$ and $\mathrm{S}$, with five replicates. Visible symptoms of nutritional deficiency were observed in the following order of omission: at 5, 12 and 20 days after transplantation in plants under omission of $\mathrm{N}, \mathrm{P}$ and $\mathrm{K}$, respectively. Conversely, there were no visible symptoms of deficiency under omissions of $\mathrm{Ca}, \mathrm{Mg}$ and $\mathrm{S}$. The sequence of growth limitation, determined based on the shoot dry mass of cherry tomato plants, was: $\mathrm{N}>\mathrm{P}>\mathrm{S}>\mathrm{Mg}>\mathrm{Ca}>\mathrm{K}$. The omission of a nutrient, besides reducing its content in the leaf tissue, causes imbalance between the other nutrients, influencing the parameters of growth and production, leading to morphological manifestations in cherry tomato.

Key words: hydroponics; mineral nutrition; Solanum lycopersicum L.; visual diagnosis

\section{Estado nutricional do tomate cereja com omissão de macronutrientes}

RESUMO: Aspectos relacionados à nutrição mineral do tomateiro (Solanum lycopersicum L.) são importantes para a produção de frutos de qualidade. $O$ tomateiro do tipo cereja (Solanum lycopersicum var. cerasiforme) é uma alternativa para grande parte dos produtores pelo seu alto valor de mercado, maior produtividade e boa aceitação por parte dos consumidores. 0 objetivo com este estudo foi avaliar o estado nutricional de tomates cereja cultivados em solução nutritiva sob omissão de macronutrientes. $O$ experimento foi conduzido em delineamento inteiramente casualizado, com sete tratamentos: solução nutritiva completa e omissões de N, P, K, Ca, Mg e S, com cinco repetições. Os sintomas visíveis de deficiência nutricional foram observados na seguinte ordem de omissão: 5, 12 e 20 dias após o transplante em plantas sob omissão de N,P e K, respectivamente. Por outro lado, não houve sintomas visíveis de deficiência sob omissões de $\mathrm{Ca}, \mathrm{Mg}$ e S. A sequência de limitação de crescimento, determinada com base na massa seca da parte aérea de tomateiro cereja, foi: $N>P>S>M g>C a>K$. A omissão de um nutriente, além de reduzir seu conteúdo no tecido foliar, causa desequilíbrio entre os demais nutrientes, influenciando os parâmetros de crescimento e produção, levando a manifestações morfológicas no tomate cereja.

Palavras-chave: hidroponia; nutrição mineral; Solanum lycopersicum L.; diagnóstico visual

\footnotetext{
*Adriana Guirado Artur - E-mail: driguirado@yahoo.com.br (Corresponding author)

Associate Editor: Mário de Andrade Lira Júnior
} 


\section{Introduction}

Tomato (Solanum lycopersicum L.) has great economic and social importance, standing out among the most consumed vegetables in the world, including Brazil, because it is cultivated in the most diverse regions of the country (Campeche et al., 2017). In 2018, tomato production in Brazil reached 4.1 million tons, an increase of $14.4 \%$ in the amount of production compared to the previous year (IBGE, 2019).

With the growing market demand for high quality products, there emerged the need to supply plants adequately with mineral nutrients, making the nutritional knowledge about the crop relevant, as it enables the analysis of morphological and anatomical aspects that are modified by changes in plant metabolism due to the specific function performed by each nutrient. Thus, experiments with omission of essential elements are used to determine the adequate mineral nutrition of cultivated plants (Flores et al., 2015; Maia et al., 2019; Martinez et al., 2020; Campos et al., 2021; Silva et al., 2021).

The sequence of nutrient absorption by tomato at the end of the production cycle under the omission of macronutrients, according to Moraes et al. (2018), is as follows: K> N> Ca> $\mathrm{S}>\mathrm{Mg}>\mathrm{P}$. Although studies on tomato nutrition have been carried out (Prado et al., 2011; Moraes et al., 2018; Maia et al., 2019), research on the diagnosis of nutritional deficiency with the omission of macronutrients in nutrient solution have been neglected.

The technique of growing plants in nutrient solution has enabled advances in the knowledge on plant nutrition and leaf diagnosis by eliminating the heterogeneity and complexity existing in the soil, because composition of the solution is more adequately controlled (Gondim et al., 2016).

Thus, the nutritional aspects of this plant should be better studied, quantifying its requirements and, consequently, its growth facilitating the taking of measures in advance, aiming to produce quality fruits. The objective with this study was to evaluate the nutritional status of cherry tomatoes grown in nutrient solution under omission of macronutrients.

\section{Materials and Methods}

The experiment was carried out in the field at the Center for Teaching and Research in Urban Agriculture (NEPAU), belonging to the Federal University of Ceará (UFC), in Fortaleza - CE, Brazil (3o 44' 18.5” S, 38 34' 23.2" W), with an altitude of $19.6 \mathrm{~m}$. According to Köppen's classification, the local climate is Aw (Alvares et al., 2013), with an average annual temperature of $26.5^{\circ} \mathrm{C}$ and annual rainfall of $1.390 \mathrm{~mm}$.

The experimental design used was completely randomized, consisting of seven treatments: complete nutrient solution and omission of macronutrients (nitrogen, phosphorus, potassium, calcium, magnesium and sulfur), with five replicates, totaling 35 experimental units.

The nutrient solutions were prepared with analytical pure reagents, having as reference the standards of the nutrient solution used by Cogo (2009), with electrical conductivity of $1.6 \mathrm{dS} \mathrm{m}^{-1}$ for tomato cultivation. The concentrations of macronutrients $\left(\mathrm{mmol} \mathrm{L}^{-1}\right)$ in the nutrient solution were: 6.25 of $\mathrm{N}, 0.46$ of $\mathrm{P}, 3.18$ of $\mathrm{K}, 1.43$ of $\mathrm{Ca}, 0.71$ of $\mathrm{Mg}$ and 0.73 of $\mathrm{S}$; and the concentrations of micronutrients $\left(\mu \mathrm{mol} \mathrm{L}^{-1}\right): 53.71$ of $\mathrm{Fe}, 9.10$ of $\mathrm{Mn}, 0.76$ of $\mathrm{Zn}, 13.88$ of $\mathrm{B}, 0.31$ of $\mathrm{Cu}$ and 0.10 of $\mathrm{Mo}$, in addition to $3.12 \mathrm{mmol} \mathrm{L}^{-1}$ of $\mathrm{Na}$. The nutrient solutions with macronutrient omission were formulated by eliminating a specific macronutrient, without modifying the concentrations of the others, according to the stock solutions of Table 1.

Cherry tomato, cultivate Carolina, was sown in a polyethylene tray with 128 cells, containing vermiculite as substrate. Five days after germination, $100 \mathrm{~mL}$ of nutrition solution with $50 \%$ of the nutrient concentration of the complete solution were applied, for better adaptation in the initial stage of the crop.

When the seedlings had three true leaves, they were transplanted to pots filled with $10 \mathrm{~L}$ of substrate, composed of

Table 1. Composition of stock solution and the volumes pipetted to prepare the complete treatment and those with omission of macronutrients for cherry tomato cultivation.

\begin{tabular}{|c|c|c|c|c|c|c|c|c|}
\hline \multirow{2}{*}{ Reagents } & \multirow{2}{*}{$\begin{array}{c}\text { Stock solution } \\
\left(\mathrm{g} \mathrm{L}^{-1}\right)\end{array}$} & Complete solution & $-N$ & $-\mathbf{P}$ & $-K$ & $-\mathrm{Ca}$ & $-\mathrm{Mg}$ & $-S$ \\
\hline & & \multicolumn{7}{|c|}{$(\mathrm{mL} \mathrm{L}-1)$} \\
\hline $\mathrm{Ca}\left(\mathrm{NO}_{3}\right)_{2}$ & 84.22 & 50 & - & 50 & 50 & - & 50 & 50 \\
\hline $\mathrm{KNO}_{3}$ & 75.48 & 50 & - & 50 & - & 50 & 50 & 50 \\
\hline $\mathrm{MgSO}_{4}$ & 50.52 & 50 & 50 & 50 & 50 & 50 & - & - \\
\hline $\mathrm{NaCl}$ & 119 & 21.5 & 21.5 & 21.5 & 3.5 & - & 16.5 & 21.5 \\
\hline $\mathrm{CaCL}_{2} 2 \mathrm{H}_{2} \mathrm{O}$ & 58.8 & - & 50 & - & - & - & - & - \\
\hline $\mathrm{NH}_{4} \mathrm{Cl}_{2}$ & 8.06 & - & - & 50 & - & - & - & - \\
\hline $\mathrm{NaNO}_{3}$ & 61.86 & - & - & - & 50 & 60 & - & - \\
\hline $\mathrm{Na}_{2} \mathrm{SO}_{4}$ & 29.1 & - & - & - & - & - & 16.5 & - \\
\hline $\mathrm{MgCl}_{2} \cdot 2 \mathrm{H}_{2} \mathrm{O}$ & 40.64 & - & - & - & - & - & - & 50 \\
\hline Rexolin $^{(1)}$ & 46.15 & 14 & 14 & 14 & 14 & 14 & 14 & 14 \\
\hline
\end{tabular}

${ }^{(1)} \mathrm{Rexolin}^{\oplus}$ : M48 (6.5 \% Fe-EDDHMA); (2)Micronutrients: $\mathrm{MnCl}_{2} 4 \mathrm{H}_{2} \mathrm{O}\left(9.006 \mathrm{~g} \mathrm{~L}^{-1}\right), \mathrm{ZnCl}_{2}\left(0.521 \mathrm{~g} \mathrm{~L}^{1}\right), \mathrm{H}_{3} \mathrm{BO}_{3}\left(4.291 \mathrm{~g} \mathrm{~L}^{-1}\right), \mathrm{CuCl}_{2} 2 \mathrm{H}_{2} \mathrm{O}\left(0.268 \mathrm{~g} \mathrm{~L}^{-1}\right)$ e NH${ }_{4} \mathrm{Mo}_{24} \mathrm{CH}_{2} \mathrm{O}\left(0.644 \mathrm{~g} \mathrm{~L}^{-1}\right) ; \mathrm{White} \mathrm{KCl}^{-}$ 
coconut powder and not carbonized rice husk, in the proportion of 2:1, based on volume. Twelve days after transplantation, the nutrient solution at $100 \%$ concentration began to be applied, according to the treatments. From this stage, $300 \mathrm{~mL}$ of the nutrient solution were applied three times a day, totaling 900 $\mathrm{mL}$ of the nutrient solution per pot per day.

Tomato plants were monitored daily for the manifestation of nutritional deficiency symptoms. Thus, it was possible to monitor the evolution of symptoms along the experimental period.

In order to verify changes in the development of tomato plants caused by nutritional deficiency, the following parameters were evaluated at sixty-six days after seedling transplantation: number of clusters plant ${ }^{-1}(\mathrm{NC})$; total number of fruits plant ${ }^{-1}$ (TNF); average fruit weight (AFW), obtained after weighing on analytical scale; fruit height $(\mathrm{FH})$, measured with a millimetric ruler from the base to the apex of the fruit; fruit diameter (FD); measured with a digital caliper; number of fruits measured (NFM), only in fruits weighing more than $3 \mathrm{~g}$; and shoot dry mass (SDM), determined on an analytical scale after drying in a forced air circulation oven at $65 \stackrel{\circ}{\circ}$, until constant weight. Fruit production per plant ${ }^{-1}$ (FPP) was calculated by counting the number of fruits per plant.

Tomato leaves were washed and then dried in forced air circulation oven at $65^{\circ} \mathrm{C}$ until constant weight. After obtaining dry mass of the leaf tissue, the material was ground in a Wiley-type mill with a 1-mm mesh for chemical analysis. Plant tissue samples were subjected to sulfuric digestion, followed by distillation and titration, to determine the total contents of nitrogen and to nitric-perchloric digestion to determine the contents of phosphorus, potassium, calcium, magnesium and sulfur, by inductively coupled plasma optical emission spectrometry (ICP-OES). These procedures are described in Miyazawa et al. (2009).

The data were subjected to analysis variance by $\mathrm{F}$ test, and treatment means were compared by the Scott-Knott test at $5 \%$ probability level, using the software program Sistema para Análises Estatísticas e Genética (SAEG), version 9.1.

\section{Results and Discussion}

\section{Visible symptomatology of plants}

Visible symptoms of nutritional deficiency were observed in the following order: N, P and K, after the treatments began. Initial symptoms of $\mathrm{N}$ deficiency were observed on the fifth day after the plants received the nutrient solution with $\mathrm{N}$ omission, indicating the importance of this macronutrient for the crop. Similar behavior was observed in bell pepper (Capsicum annuum) by Silva et al. (2019), who found that the first symptom of deficiency was caused by the absence of nitrogen in the nutrient solution.

Plants under $\mathrm{N}$ omission initially showed yellowing (chlorosis) on the blade and petiole of older leaves, which evolved until the occurrence of premature senescence of the old leaves. This chlorosis of older tissues results from proteolysis in chloroplasts, where amino acids are mobilized to younger leaves, which leads to decrease in chlorophyll content (Marschner, 2018). When chlorophyll decreases, the photosynthetic rate is severely reduced, so there is a deficit in biomass accumulation and growth of tomato plants, according to Khavari-Nejad et al. (2009).

In addition, the plants produced small and chlorotic new leaves, with reduced growth (stunted plants). Typically, plants show this decrease in growth because of the damage to the synthesis of proteins and chlorophyll and to the enzymatic activation, leading to premature senescence of older leaves from which the element is remobilized to the younger ones (Aguera \& Haba, 2018).

Tomato plants grown in P-deficient solution showed visible symptoms of deficiency twelve days after the treatments began, with reduction of growth and exhibiting dark green and small leaves and small and thin stems. With the evolution of symptoms, mild marginal chlorosis was observed followed by generalized necrosis of the leaves, which remained attached to the stems. Similar symptoms have been described by Maia et al. (2019) for cherry tomato (Solanum lycopersicum L.).

$P$ was the second element to cause symptoms, indicating that it is limiting for cherry tomato cultivation, due to its importance in plant metabolism (Fan et al., 2018) specifically in the biosynthesis of DNA, RNA and phosphate esters, such as phospholipids, which are an important $P$ reservoir in plants, even under conditions where the growth is limited by P (Okazaki et al., 2015).

Twenty days after the treatments began, plants grown in solution with $\mathrm{K}$ omission showed chlorosis on the margins and tips of older leaves, evolving to necrosis. Symptoms initially appear in older leaves due to the easy mobility of $\mathrm{K}$ to younger leaves (Taiz et al., 2017).

Plants grown in nutrient solution with omission of $\mathrm{Ca}, \mathrm{Mg}$ and $\mathrm{S}$ did not exhibit visible symptoms of deficiency of these elements. Sturião et al. (2020) observed anatomical changes in leaf and stem tissues in cherry tomato cultivar Iracema under omission of $\mathrm{Ca}$. However, these authors emphasized that the manifestation of symptoms depends on the genotype and the environment. Maia et al. (2019) and Martinez et al. (2020) did not observe visual symptoms in cherry tomato cultivar Sindy under omission of $\mathrm{Ca}$ in the nutrient solution, corroborating the result found in the present research. These authors, in turn, concluded that this cultivar studied requires a low requirement for this nutrient. Probably, the cultivar Cerasiforme has low requirement of these nutrients.

\section{Growth and production}

Tomato plants grown under $\mathrm{N}$ omission showed an approximate reduction of $91.6 \%$ in shoot dry mass (SDM). In addition, there were also reductions of $26.2,95.7$ and $92.8 \%$ in the average fruit weight (AFW), fruit production per plant (FPP) and number of clusters (NC), respectively, compared to the complete treatment (Table 2).

Fruits collected in the treatment under $\mathrm{N}$ omission were considered small $(1.91 \mathrm{~cm}$ length and $1.62 \mathrm{~cm}$ diameter) and, among them, only two fruits weighed more than $3 \mathrm{~g}$. Fruits 
Table 2. Growth and production parameters of cherry tomato, cv. Carolina, grown in complete nutrient solution and with individual omission of macronutrients.

\begin{tabular}{|c|c|c|c|c|c|c|c|c|}
\hline \multirow{2}{*}{ Treatment } & SDM & AFW & FPP & \multirow{2}{*}{ NC } & \multirow{2}{*}{ TNF } & \multirow{2}{*}{ NFM } & $\mathrm{FH}$ & FD \\
\hline & & (g) & & & & & \multicolumn{2}{|c|}{ (cm) } \\
\hline Complete & $78.9 a$ & $6.07 a$ & $312.7 \mathrm{a}$ & $19.4 \mathrm{a}$ & $73.0 \mathrm{a}$ & $51.2 \mathrm{a}$ & $2.71 \mathrm{a}$ & $2.25 \mathrm{a}$ \\
\hline$-N$ & $6.6 \mathrm{c}$ & $4.48 \mathrm{~b}$ & $13.5 \mathrm{~b}$ & $1.4 \mathrm{~b}$ & $2.2 \mathrm{c}$ & $2.0 \mathrm{c}$ & $1.91 \mathrm{~b}$ & $1.62 \mathrm{a}$ \\
\hline$-K$ & $69.6 \mathrm{~b}$ & $7.34 \mathrm{a}$ & $370.1 \mathrm{a}$ & $18.2 \mathrm{a}$ & $64.4 \mathrm{~b}$ & $50.4 \mathrm{a}$ & $2.78 \mathrm{a}$ & $2.29 a$ \\
\hline -Ca & $64.2 \mathrm{~b}$ & $7.05 \mathrm{a}$ & 384.9 a & $19.2 \mathrm{a}$ & $76.6 \mathrm{a}$ & $54.6 a$ & $2.72 \mathrm{a}$ & $2.18 \mathrm{a}$ \\
\hline$-M g$ & $61.8 b$ & $7.02 \mathrm{a}$ & $385.1 \mathrm{a}$ & $17.6 a$ & $67.2 b$ & $54.8 a$ & $2.91 \mathrm{a}$ & $2.16 a$ \\
\hline C. V. (\%) & 13.5 & 13.4 & 22.3 & 13.4 & 11.0 & 11.3 & 16.4 & 17.2 \\
\hline
\end{tabular}

SDM: shoot dry mass; AFW: average fruit weight; FPP: Fruit production per plant ${ }^{-1}$; NC: number of clusters plant ${ }^{-1}$; TNF: total number of fruits plant ${ }^{-1}$; NFM: number of fruits measured $\mathrm{FH}$ : fruit height; FD: fruit diameter. Means followed by the same letter do not differ statistically by Scott and Knott test at $5 \%$ probability.

with sizes between 2.0 and $3.0 \mathrm{~cm}$ are considered the most demanded by consumers (Rodrigues et al., 2008). Thus, only treatment under $\mathrm{N}$ omission produced small fruits. In relation to the biometric variables evaluated, all values were lower than those found in the complete treatment, except for fruit diameter, which did not differ statistically.

$\mathrm{N}$ deficiency in tomato drastically reduces the photosynthetic rate and thus inhibits the production of photoassimilates (Kanai et al., 2008), since part of the total leaf $\mathrm{N}$ is allocated in the enzymes RuBisCO and phosphoenolpyruvate carboxylase, responsible for fixing atmospheric $\mathrm{CO}_{2}$ (Marschner, 2018).

Thus, when nitrogen deficiency occurs, that is, when the $\mathrm{N}$ content in the plant is below optimal, several physiological processes are compromised, resulting in the inhibition of growth and fruit production parameters, which depend on photoassimilates, corroborating what was previously observed by Flores et al. (2015) in eggplant plants under omission of $\mathrm{N}$.

In the treatment with $\mathrm{P}$ omission, significant effects were caused on both plant growth, with $90.5 \%$ reduction in SDM, and fruit production, with reductions from 312.7 to $11.7 \mathrm{~g}$ in FPP, from 19.4 to 1.5 in NC and from 51.2 to 1.7 in NFM, with only two fruits per plant weighing more than $3 \mathrm{~g}$, compared to the complete treatment.

The results of the present study reveal that for cherry tomatoes, P deficiency is limiting, because this nutrient is fundamental for obtaining significant increases in growth, as plants grown in P-deficient nutrient solution significantly reduce their concentrations of sugars and soluble proteins, which results from the reduction of the phosphorylation process in protein biosynthesis (Khavari-Nejad et al., 2009).

Potassium omission resulted in lower SDM and TNF, with a reduction of $11.8 \%$ for both, compared to the treatment with complete nutrient solution. The absence of $K$ results in losses to the plant, since this element acts in osmoregulation, transpiration, leaf growth and biomass production (Marschner, 2018).

Nevertheless, under $\mathrm{K}$ omission the fruit production per plant was equal to $18.3 \%$, higher than the production of plants grown with complete nutrient solution, which can be explained by the higher average weight of fruits obtained in plants under $\mathrm{K}$ omission. These results confirm the importance of K during fruit formation. Ho \& Adams (1995) highlighted that this nutrient is accumulated in the tomato fruit to standardize ripening and increase its acidity levels, so $\mathrm{K}$ is responsible for the quality and taste of the fruit, attributed to its function in the transport of photoassimilates through the phloem (Pacheco et al., 2018).

Tomato plants grown under $\mathrm{Ca}$ omission had lower SDM, with a reduction of $18.6 \%$ in comparison to the complete treatment, because of the negative effect on shoot growth. Although $\mathrm{Ca}$ has significant importance during the maintenance of the functional integrity of the membranes, for reducing intercellular spaces in cherry tomatoes (Islam et al., 2016), the characteristics of fruit production were not affected by its omission in the nutrient solution. A possible justification is that $\mathrm{Ca}$ accumulates preferably in the leaves, as it is transported through the xylem, and therefore, in a smaller quantity, is accumulated in the fruits (Bar-Tal et al., 2017).

In tomato plants cultivated in nutrient solution with $\mathrm{Mg}$ omission, significant difference was only observed for SDM, with a decrease of $21.7 \%$ compared to the complete treatment.

Plants subjected to absence of $\mathrm{Mg}$ showed reduced dry mass accumulation, because the omission of this nutrient affects the functionality of chloroplasts, including size and structure, and consequently, dry mass accumulation, since the element is a constituent of the chlorophyll molecule (Marschner, 2018).

For the omission of $S$ in the nutrient solution, the variables that showed significant differences were SDM, TNF and NFM, which decreased by $23.6,11.8$ and $11.3 \%$, respectively, in comparison to the complete treatment. $\mathrm{S}$ is fundamental for crops, in general, because it is a constituent of amino acids that are essential for plant growth, such as methionine and cysteine (Moraes et al., 2018). Thus, in the absence of S, cell division is affected, which limits the growth and reproductive stage of plants.

\section{Contents of nutrients}

Leaf contents of $\mathrm{N}$ and $\mathrm{P}$ ranged from 6.2 to 32.3 and from 0.7 to $5.6 \mathrm{~g} \mathrm{~kg}^{-1}$, respectively, in all treatments (Table 3 ). These contents are below to the range observed by Bastos et al. (2013) for tomato leaves, which varies from 40.0 to $60.0 \mathrm{~g} \mathrm{~kg}^{-1}$ 
Table 3. Leaf contents of macronutrients in cherry tomato grown with omission of nutrients.

\begin{tabular}{|c|c|c|c|c|c|c|}
\hline \multirow{2}{*}{ Treatment } & $\mathbf{N}$ & $\mathbf{P}$ & $\mathrm{K}$ & $\mathrm{Ca}$ & $\mathrm{Mg}$ & 5 \\
\hline & \multicolumn{6}{|c|}{$\left(\mathrm{g} \mathrm{kg}^{-1}\right)$} \\
\hline Complete & $12.0 \mathrm{c}$ & $2.8 \mathrm{c}$ & $8.0 \mathrm{~b}$ & $27.8 \mathrm{c}$ & $22.6 \mathrm{~b}$ & $14.4 \mathrm{~b}$ \\
\hline$-N$ & $6.2 \mathrm{~d}$ & $5.6 a$ & $11.6 \mathrm{a}$ & $18.8 \mathrm{~d}$ & $16.5 \mathrm{C}$ & $13.6 \mathrm{~b}$ \\
\hline$-P$ & $32.3 \mathrm{a}$ & $0.7 d$ & $12.5 \mathrm{a}$ & 45.9 a & 28.9 a & $5.7 c$ \\
\hline$-K$ & $15.0 \mathrm{~b}$ & $4.4 b$ & $3.4 \mathrm{~d}$ & $32.8 b$ & 30.7 a & $18.0 \mathrm{a}$ \\
\hline$-\mathrm{Ca}$ & $14.6 \mathrm{~b}$ & $2.9 \mathrm{c}$ & $8.3 \mathrm{~b}$ & $21.9 \mathrm{~d}$ & $32.3 \mathrm{a}$ & $16.3 \mathrm{a}$ \\
\hline$-\mathrm{Mg}$ & $12.0 \mathrm{C}$ & $2.7 c$ & $7.4 \mathrm{~b}$ & $33.8 \mathrm{~b}$ & $19.4 \mathrm{C}$ & $16.1 \mathrm{a}$ \\
\hline$-S$ & $12.9 \mathrm{c}$ & $2.8 \mathrm{c}$ & $6.0 \mathrm{c}$ & $48.4 \mathrm{a}$ & $22.5 \mathrm{~b}$ & $1.6 \mathrm{~d}$ \\
\hline C. V. $(\%)$ & 12.2 & 10.8 & 13.9 & 10.8 & 10.5 & 18.9 \\
\hline
\end{tabular}

Means followed by the same letter do not differ statistically by Scott and Knott test at $5 \%$ probability.

for $\mathrm{N}$ and from 4.0 to $8.0 \mathrm{~g} \mathrm{~kg}^{-1}$ for P. However, these contents were sufficient for the growth and production of cherry tomato plants, since they did not show visible symptoms of deficiency of these elements in the complete treatment. The leaf contents of nutrients vary with the cultivar.

$\mathrm{N}$ omission resulted in increased leaf contents of $\mathrm{P}$ $(100 \%)$ and $K(45 \%)$, while reducing the content of the other macronutrients in comparison to the complete nutrient solution.

$\mathrm{P}$ omission caused lower SDM production, which led to increments in the contents of the other nutrients under this condition, which was possibly due to the concentration effect in plant tissues. The vegetative growth period in the plant comprises the moment when there is the highest absorption of nutrients, which results in greater accumulation in the plant tissue (Marschner, 2018). On the other hand, when the plant ceases its initial growth, the concentration of nutrients in the tissues decreases, because they are being demanded for reproduction.

The contents of $\mathrm{N}, \mathrm{K}, \mathrm{Ca}$ and $\mathrm{Mg}$ in tomato leaves increased by $169.2,56.2,65.1$ and $27.9 \%$, respectively, with $P$ omission in the nutrient solution, compared to the complete treatment. The opposite occurred with the $\mathrm{S}$ content, which decreased by $60.4 \%$.

$\mathrm{N}$ and $\mathrm{P}$ were the most limiting elements for cherry tomato in relation to the leaf contents of the macronutrients analyzed. Indeed, the tomato crop has high response when nutrients are supplied in satisfactory quantities. In a study conducted by Abdelhady et al. (2017) to evaluate the growth and production of tomato fruits under different levels of irrigation and rates of NPK fertilization, these authors stated that vegetative growth, yield and quality of tomato fruits are negatively affected by the decrease in NPK fertilization rate. Additionally, according to the same authors, fertilization with adequate NPK levels can minimize the harmful effects caused by the stress due to water deficit.

$\mathrm{K}$ omission increased the contents of the other macronutrients ( $\mathrm{P}, \mathrm{Mg}, \mathrm{S}, \mathrm{N}$ and $\mathrm{Ca}$ ) by $57.1,35.8,25.0,25.0$ and $18 \%$, respectively, when compared to the complete treatment. The increase in $\mathrm{Ca}, \mathrm{Mg}$ and $\mathrm{N}$ contents in leaf tissues may occur probably in response to the absence of the mechanism of competitive inhibition among $\mathrm{Ca}, \mathrm{Mg}$ and $\mathrm{K}$, which contributes to the absorption of these elements. In addition, competition may occur among these ions of similar chemical characteristics, especially $\mathrm{K}$ and $\mathrm{Mg}$, not only in the absorption by roots, but also during their transport to the aerial part of the plant (Li et al., 2018), leading to imbalance in the leaf contents of these nutrients.

The leaf content of $\mathrm{Mg}$ in cherry tomato under complete nutrient solution was equal to $22.6 \mathrm{~g} \mathrm{~kg}^{-1}$, while in the treatment with omission of this element the content was $19.4 \mathrm{~g} \mathrm{~kg}^{-1}$. These contents are above the range considered adequate for tomato, from 4.0 to $8.0 \mathrm{~g} \mathrm{~kg}^{-1}$ (Bastos et al., 2013). In addition, Mg contents increased by $42.9 \%$ with $\mathrm{Ca}$ omission and $35.8 \%$ with $\mathrm{K}$ omission.

The Ca contents in the leaves of plants grown in complete nutrient solution $\left(27.8 \mathrm{~g} \mathrm{~kg}^{-1}\right)$ and under omission of this nutrient $\left(21.9 \mathrm{~g} \mathrm{~kg}^{-1}\right)$ are within the range considered adequate for tomato plants, from 14.0 to $40.0 \mathrm{~g} \mathrm{~kg}^{-1}$ (Bastos et al., 2013).

With $\mathrm{Ca}$ omission, the contents of $\mathrm{N}, \mathrm{Mg}$ and $\mathrm{S}$ in tomato leaves increased by $21.7,42.9$, and $13.2 \%$, respectively, while $\mathrm{P}$ and $\mathrm{K}$ contents were not affected compared to the complete treatment. The increase in the leaf contents of $\mathrm{N}, \mathrm{Mg}$ and $\mathrm{S}$ was possibly due to the effect of concentration in plant tissues, given the lower SDM production (18.6\%) in comparison to the complete treatment.

The absence of $\mathrm{Ca}$ and $\mathrm{K}$ in the solution individually influenced the contents of $\mathrm{K}, \mathrm{Ca}$ and $\mathrm{Mg}$, and the greater absorption of one to the detriment of the other caused imbalance in their leaf contents. This is justified by the interionic competition for the same absorption sites in the membrane, being one of the most important causes of their deficiency in plant tissue (Marschner, 2018). It is worth pointing out that this competition only occurs when one of the elements is supplied in a lower quantity than that required by the plant, so low concentrations of one element favor the increase in the absorption of the other by the plant (Marschner, 2018). This is clearly observed in the increase in Ca content $(74.1 \%)$ and decrease of $25 \%$ in the leaf content of $\mathrm{K}$, in the treatment with omission of $\mathrm{S}$ in the nutrient solution.

\section{Conclusions}

The nutritional status of cherry tomatoes grown in nutrient solution was affected by the omission of macronutrients. Cherry tomato exhibits visible symptoms of deficiency caused by $\mathrm{N}, \mathrm{P}$ and $\mathrm{K}$, indicating that these are the most limiting nutrients to growth and fruit production. 
The omission of a nutrient, besides reducing its content in the leaf tissue of cherry tomatoes, causes nutritional imbalance among the other nutrients.

\section{Compliance with Ethical Standards}

Author contributions: Conceptualization: IS, JCSR; Data curation: IS, JCSR; Formal analysis: IS, JCSR; Investigation: IS, JCSR; Methodology: IS; Project administration: IS; Resources: IS; Supervision: IS, AGA; Validation: IS, AGA; Visualization: IS, JCSR; Writing - original draft: HAFA, IGV, IMSO, AGA; Writing review \& editing: HAFA, AGA.

Conflict of interest: We have no conflicts of interest to disclose.

Financing Source: No financial support.

\section{Literature Cited}

Abdelhady, S.A.; El-Azm, N.A.I.A.; El-Kafafi, E.H. Effect of deficit irrigation levels and NPK fertilization rates on tomato growth, yield and fruits quality. Middle East Journal of Agriculture, v.6, n.3, p. 587-604, 2017. http://www.curresweb.com/mejar/ mejar/2017/587-604.pdf. 22 Jun. 2020.

Aguera, E.; Haba, P. de L. Leaf senescence in response to elevated atmospheric $\mathrm{CO}_{2}$ concentration and low nitrogen supply. Biologia Plantarum, v.62, n.3, p.401-408, 2018. https://doi.org/10.1007/ s10535-018-0798-z.

Alvares, C.A.; Stape, J.L.; Sentelhas, P.C.; Gonçalves, J.L.M.; Sparovek. G. Köppen's climate classification map for Brazil. Meteorologische Zeitschrift, v.22, n.6, p.711-728, 2013. https:// doi.org/10.1127/0941-2948/2013/0507.

Bar-Tal, A. D.; Yermiyahu, U.; Ben-Gal, A.; Schwartz, A.; Faingold, I.; Seligmann, R. Optimization of calcium and magnesium concentrations for fertigation of tomato with desalinated water. Israel Journal of Plant Sciences, v.64, n.3, p.80-91, 2017. https:// doi.org/10.1080/07929978.2017.1288466.

Bastos, A.R.R.; Alvarenga, M.A.R.; Carvalho, J.G.; Pinho, P.J. Nutrição mineral e adubação. In: Alvarenga, M.A.R. (Ed.). Tomate: produção em campo, em casa de vegetação e em hidroponia. Lavras: UFV, 2013. p.65-130.

Campeche, L.F.S.M.; Franca, R.J.F.; Leitão, M.M.V.B.R.; Silva, J.S.; Paz, V.P.S. Microclima e evapotranspiração de tomate em dois sistemas de produção no vale do São Francisco. Agrometeoros, v.25, n.1, p.133-142, 2017. https://doi.org/10.31062/agrom.v25i1.26274.

Campos, C.N.S.; Teixeira, G.G.M.; Prado, R. de M.; Caione, G.; Silva Júnior, G.B. da S.; David, C.H.O. de.; Sales, A.C.; Roque, C.G.; Teodoro, P.E. Macronutrient deficiency in cucumber plants: impacts in nutrition, growth and symptoms. Journal of Plant Nutrition, 2021. https:// doi.org/10.1080/01904167.2021.1921205.

Cogo, C.M. Crescimento, produtividade e consumo de solução nutritiva em diferentes concentrações pelo tomateiro cultivado em casca de arroz in natura. Pelotas: Universidade Federal de Pelotas, 2009. 56p. PhD Thesis. http://guaiaca.ufpel.edu. br:8080/handle/123456789/2396. 12 Jun. 2020.

Fan, Y.V.; Lee, C.T.; Klemes, J.J.; Chua, L.S.; Sarmidi, M.R.; Leow, C.W. Evaluation of effective microorganisms on home scale organic waste composting. Journal of Environmental Management, v.216, p.41-48, 2018. https://doi.org/10.1016/j.jenvman.2017.04.019.
Flores, R.A.; Borges, B.M.M.N.; Almeida, H.J.; Prado, R.M. Growth and nutritional disorders of eggplant cultivated in nutrients solutions with suppressed macronutrients. Journal of Plant Nutrition, v.38, n.7, p.1097-1109, 2015. https://doi.org/10.1080/01904167.201 4.963119 .

Gondim, A.R.O.; Prado, R.M.; Fonseca, I.M.; Alves, A.U. Crescimento inicial do milho cultivar BRS1030 sob omissão de nutrientes em solução nutritiva. Revista Ceres, v.63, n.5, p.706-714, 2016. https://doi.org/10.1590/0034-737×201663050016.

Ho, L.C.; Adams, P. Nutrient uptake and distribution in relation to crop quality. Acta Horticulturae, v.396, n.3, p.33-44, 1995. https://doi. org/10.17660/ActaHortic.1995.396.3.

Instituto Brasileiro de Geografia e Estatística - IBGE. Produção Agrícola Municipal 2019. https://sidra.ibge.gov.br/ tabela/1612\#resultado. 12 Jun. 2020.

Islam, M.Z.; Mele, M.A.; Baek, J.P.; Kang, H. Cherry tomato qualities affected by foliar spraying with boron and calcium. Horticulture, Environment, and Biotechnology, v.57, n.1, p.46-52, 2016. https://doi.org/10.1007/s13580-016-0097-6.

Kanai, S.; Adu-Gymfi, J.; Lei, K.; Ito, J.; Ohkura, K.; Moghaieb, R.E.A; El-Shemy, H.; Mohapatra, R.; Mohapatra, P.K.; Saneoka, H.; Fujita, K. N-deficiency damps out circadian rhythmic changes of stem diameter dynamics in tomato plant. Plant Science, v.174, n.2, p.183-191, 2008. https://doi.org/10.1016/j.plantsci.2007.11.006.

Khavari-Nejad, R.A.; Najafi, F.; Tofighi, C. Diverse responses of tomato to $\mathrm{N}$ and $\mathrm{P}$ deficiency. International Journal of Agriculture and Biology, v.11, n.2, p.209-213, 2009. http://www.fspublishers.org/ published_papers/93814_..pdf. 26 May. 2020.

Li, H.; Chen, Z.; Zhou, T.; Liu, Y.; Raza, S.; Zhou, J. Effects of high potassium and low temperature on the growth and magnesium nutrition of different tomato cultivars. HortScience, v.53, n.5, p.710-714, 2018. https://doi.org/10.21273/HORTSCI12983-18.

Maia, J.T.L.S.; Martinez, H.E.P.; Clemente, J.M.; Ventrella, M.C.; Milagres, C.C. Growth, nutrient concentration, nutrient accumulation and visual symptoms of nutrient deficiencies in cherry tomato plants. Semina: Ciências Agrárias, v.40, n.2, p.585598, 2019. https://doi.org/10.5433/1679-0359.2019v40n2p585.

Marschner, H. Mineral Nutrition of higher plants. 3.ed. San Diego: Academic Press, 2018. 672p.

Martinez, H.E.P.; Maia, J.T.L.S.; Ventrella, M.C.; Milagres, C. do C.; Cecon, P.R.; Clemente, J.M.; Garbin, C.Z. Leaf and stem anatomy of cherry tomato under calcium and magnesium deficiencies. Brazilian Archives of Biology and Technology, v.63, p. e20180670, 2020. https://doi.org/10.1590/1678-4324-2020180670.

Miyazawa, M.; Pavan, M.A.; Muraoka, T.; Carmo, C.A.F.S.; Melo, W.J. Análise química de tecido vegetal. In: Silva, F.C. da (Ed.). Manual de análises químicas de solos, plantas e fertilizantes. 2.ed. Brasília: Embrapa Informação Tecnológica ,2009. p.191-234.

Moraes, C.C.; Factor, T.; Araújo, H.S.; Purquerio, L.F.V. Plant growth and nutrient accumulation in two tomato hybrids under tropical conditions. Australian Journal of Crop Science, v.12, n.9, p.14191425, 2018. https://doi.org/10.21475/ajcs.18.12.09.PNE1076.

Okazaki, Y.; Nishizawa, T.; Takano, K.; Ohnishi, M.; Mimura, T.; Saito, K. Induced accumulation of glucuronosyldiacylglycerol in tomato and soybean under phosphorus deprivation. Physiologia Plantarum, v.155, n.1, p.33-42, 2015. https://doi.org/10.1111/ppl.12334. 
Pacheco, A.B.; Silva, T.J.A.; Bonfim-Silva, E.M.; Castro, H.A.W.; Koetz, M. Yield and water use of cherry tomato under water availability and potassium doses. Revista Brasileira de Engenharia Agrícola e Ambiental, v.22, n.5, p.326331, 2018. https://doi.org/10.1590/1807-1929/agriambi. v22n5p326-331.

Prado, R.M.; Santos, V.H.G.; Gondim, A.R.O.; Alves, A.U.; Cecílio Filho, A.B.; Correia, M.A.R. Crescimento e marcha de absorção de nutrientes em tomateiro cultivar Raísa cultivado em sistema hidropônico. Semina: Ciências Agrárias, v.32, n.1, p.19-30, 2011. https://doi.org/10.5433/1679-0359.2011v32n1p19.

Rodrigues, M.B.; Dornelles, A.L.C.; Silva, V.O.M.Z.; Pessoa, C.A.; Serralha, B.C.S.; Silva, D.A.G.; Pereira, M.B. Caracterização morfológica de 25 cultivares de tomateiro tipo cerejacaracteres da planta. Horticultura Brasileira, v.26, n.1, p.22614467, 2008. http://www.abhorticultura.com.br/EventosX/ Trabalhos/EV_2/A1111_T2286_Comp.pdf. 22 Jun. 2020.
Silva, M.P.S. da S.; Freitas, M.S.M.; José, A.P.P.; Santos, P.C. dos; Carvalho, A.J.C. de; Vieira, I.J.C.; Rodrigues, R. Capsaicinoids and mineral composition of peppers produced under nutrient deficiencies. Journal of Plant Nutrition, v.44, n.6, p.845-853, 2021. https://doi.org/10.1080/01904167.2021.1871752.

Silva, M.P.S.; Freitas, M.S.M.; Santos, P.C.; Carvalho, A.J.C.; Jorge, T.S. Capsicum annuum var. annuum under macronutrients and boron deficiencies: leaf content and visual symptoms. Journal of Plant Nutrition, v.42, n.5, p.417-427, 2019. https://doi.org/10.1080/01 904167.2018.1544255.

Sturião, W.P.; Martinez, H E.P.; Oliveira, L.A., Jezler, C.N., Pereira, L.J; Ventrella, M.C.; Milagres, C.C do. Deficiency of calcium affects anatomical, biometry and nutritional status of cherry tomato. South African Journal of Botany, v.132, p.346-354, 2020. https:// doi.org/10.1016/j.sajb.2020.05.003.

Taiz, L., E. Zeiger, I. Moller and A. Murphy. Fisiologia e desenvolvimento vegetal. 7.ed. Porto Alegre: ArtMed, 2017. 888p. 